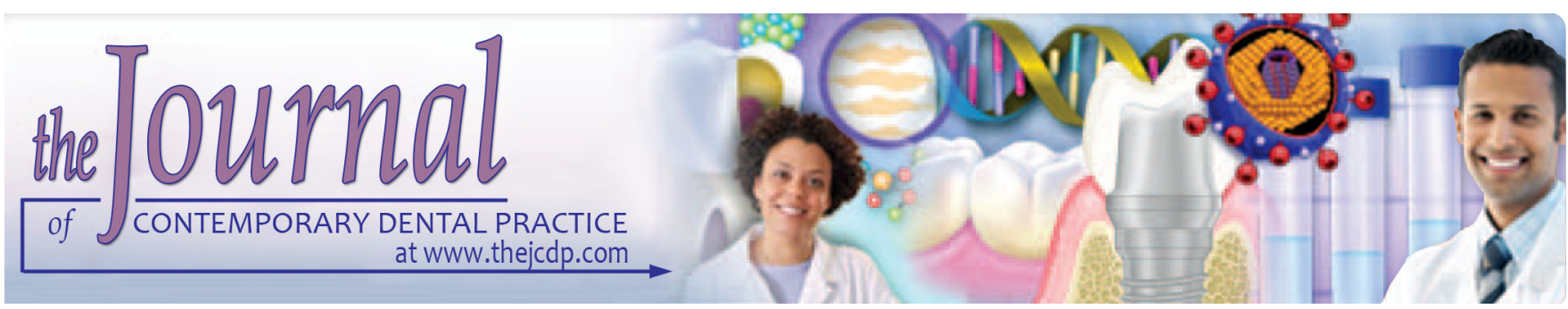

\title{
Evaluation of the Surface Roughness and Microleakage of Dental Composites Exposed to Different Beverages
}

\author{
${ }^{1}$ Marcos Aurélio Bonfim da Silva, ${ }^{2}$ Rafael Pino Vitti, ${ }^{3}$ Mário Alexandre Coelho Sinhoreti \\ ${ }^{4}$ Rafael Leonardo Xediek Consani, ${ }^{5}$ José Ginaldo da Silva Júnior, ${ }^{6}$ Josealdo Tonholo
}

\section{ABSTRACT}

Aim: The purpose of this study was to determine the effect of different solutions cola soft drink (CSD) and coffee on roughness and microleakage of composite resin restorations.

Materials and methods: Sixty bovine incisors were prepared and restored using Filtek Z350 XT (3M/ESPE) nanoparticulate resin. The samples were divided into three groups $(n=20)$ : $A$ (control)-Immersion in artificial saliva (14 days); B: Immersion in coffee (14 days), for 15 minutes (3x/day) and C: Immersion in CSD for 14 days ( $3 x /$ day). Then the samples were analyzed for microleakage (dye penetration) and surface roughness (atomic force microscope). The one-way analysis of variance (ANOVA) was applied to assess the surface roughness and microleakage. The Tukey's test was set at 0.05 .

Results: Group A (roughness-GA $A_{R}$ ) presented significantly the lowest average surface roughness. Group C (microleakage$\mathrm{GC}_{\mathrm{M}}$ ) showed significantly the highest average microleakage.

Conclusion: It was concluded that CSD and coffee change the surface roughness and increase the microleakage of restorations.

${ }^{1}$ Department of Restorative Dentistry, Alagoas Federal University, Alagoas, Brazil

${ }^{2}$ Department of Prosthodontics, University of Taubaté, São Paulo, Brazil

${ }^{3}$ Department of Restorative Dentistry, University of Campinas São Paulo, Brazil

${ }^{4}$ Department of Prosthodontics and Periodontics, University of Campinas, São Paulo, Brazil

${ }^{5}$ Department of Chemistry, Alagoas Federal Institute, Alagoas Brazil

${ }^{6}$ Department of Chemistry and Biotechnology, Institute of Chemistry and Biotechnology, Alagoas Federal University Alagoas, Brazil

Corresponding Author: Rafael Pino Vitti, Professor Department of Prosthodontics, University of Taubaté, São Paulo, Brazil, Phone: +551236292130, e-mail: rafapvitti@ gmail.com
Clinical significance: Nowadays there is a high consumption of artificially sweetened soft drinks, sports drinks, high-energy beverages and coffee products by people that cause problems in composite resin restorations.

Keywords: Artificial saliva, Beverages, Dental restoration, Microleakage, Surface roughness.

How to cite this article: da Silva MAB, Vitti RP, Sinhoreti MAC, Consani RLX, da Silva JGJ, Tonholo J. Evaluation of the Surface Roughness and Microleakage of Dental Composites Exposed to Different Beverages. J Contemp Dent Pract 2015;16(10):800-804.

Source of support: Nil

Conflict of interest: None

\section{INTRODUCTION}

Recently, there was an increased in the consumption of artificially sweetened soft drinks, sports drinks, high-energy beverages and coffee products by people. ${ }^{1}$ Attention has been given to the role of diet in the etiology of resin composite degradation. ${ }^{2}$ Dental materials placed in oral cavity undergo thermal, mechanical and chemical influences, promoting a frequent oral degradation process. The fact of coffee, teas, and cola soft drink (CSD) contain acids in their composition and be highly consumed may jeopardize the properties of dental composite. ${ }^{3}$

One of the most important properties that determine the durability of dental materials in the oral cavity is strength to dissolution or disintegration. ${ }^{4}$ The critical oral environment conditions, i.e. $\mathrm{pH}$ changes and humidity, may increase resin composite degradation over time..$^{5}$ It has been known for a long time that acidic food and drinks may soften dental hard tissues. This process may also deteriorate the mechanical properties of the material and reduce the clinical life of composite resin restorations. ${ }^{6}$

Dental erosion not only affects the dental enamel. When reaching dentin the erosion can cause hypersensitivity, or in severe cases, pulp exposure and even tooth fracture. ${ }^{7}$ Studies reported that acidic condition degraded glass 
ionomer cements, polyacid modified resin composites, and restorative composite. ${ }^{8}$

There was always great interest in the fit of restorative materials to the walls of cavities and in the retentive ability of the material to seal the cavity against the penetration of microorganisms and saliva. ${ }^{9}$ Microleakage in restorative materials is a big problem in clinical dentistry. ${ }^{10}$ Composite may exhibit reduced properties along time, which increases it susceptibility to wear and marginal microleakage when in contact with liquids. ${ }^{11}$

Thus, coffee and CSD were selected for this study to evaluate the influence of these beverages on the superficial roughness and marginal microleakage of composite resin restorations. The hypothesis was that the roughness and microleakage of dental composite would be affected by CSD and coffee.

\section{MATERIALS AND METHODS}

\section{Specimens Preparation}

A total of 60 bovine incisors were used, free of stains, caries, cracks and other defects visible. The bovine teeth were cleaned and stored in physiological solution at $37^{\circ} \mathrm{C}$ until the moment where the cavities were prepared. The teeth were sectioned $3 \mathrm{~mm}$ from the amelo-cement junction by IsoMet ${ }^{\circledR} 1000$ (Buehler, Lake Bluff, IL, USA).

The cavities were performed on vestibular surface of the bovine incisors, using a diamond bur (KG Sorensen, Barueri, SP, Brazil). A silicon cursor (Ângelus, Londrina, PR, Brazil) was placed $2 \mathrm{~mm}$ from the end of the bur's active tip to standardize the cavities depth. Then, the cavities showed a rectangular form with $6 \mathrm{~mm}$ in the medial-distal, $3 \mathrm{~mm}$ in the cervical-incisal, $2 \mathrm{~mm}$ in depth directions, and a cavosurface angle in the enamel.

After the cavities preparation, the teeth were cut in blocks with approximately $1 \mathrm{~cm}^{2}$. The surfaces were sandpapered $(600,1200$ grit $)$ and polished with a diamond disk (KG Sorensen, Barueri, SP, Brazil). The cavities were cleaned using pumice stone/water and by ultrasound.

The samples were restored with Filtek Z350 XT (3M/ ESPE, St Paul, MN, USA), shade A2E, Adper Single Bond 2 adhesive (3M/ESPE, Sumaré, SP, Brazil) and $37 \%$ phosphoric acid (SDI, São Paulo, Brazil), following the manufacturer's instructions. The composite resin was placed in a single increment $(2 \mathrm{~mm})$ and photocured for 40 seconds with a light-emitting diode-LED (Gnatus, Ribeirão Preto, SP, Brazil). The light output was constantly monitored by a radiometer with an average of $1200 \mathrm{~mW} / \mathrm{cm}^{2}$ (Demetron, Kerr Corp, Orange, CA, USA).

After the specimens were polished with Diamond PRO (2-4 $\mu \mathrm{m})$ polishing disks (FGM, Joinvile, SC, Brazil), diamond paste $(0.03 \mu \mathrm{m})$ and water, similar to clinical practice. Then, the specimens were cleaned ultrasonically and dried.

\section{Cycling of the Specimens}

The specimens were divided into three groups $(n=20)$ as described in Table 1. It was used 14 bottles of CSD (Coca-Cola ${ }^{\circledR}$, Maceió, AL, Brazil) and a coffee (Pilão ${ }^{\circledR}$, Jundiaí, SP, Brazil). The coffee was prepared using a 1:10 ratio (powder: water). The composition is listed in Table 2. Between the cycles, each specimen was stored in $1.2 \mathrm{ml}$ of artificial saliva at $37^{\circ} \mathrm{C}$ (Pharmacêutico ${ }^{\circledR}$, Maceió, AL, Brazil). An amount of $10 \mathrm{ml}$ of the corresponding solution (coffee and CSD) was added in a glass container with each sample. The samples were cleaned and dried using absorbent paper. The $\mathrm{pH}$ was determined using a portable pH meter (Orion Model 420 A, Analyzer, São Paulo, Brazil). The testing period and solution immersion period followed the protocol used by von Fraunhofer and Rogers. ${ }^{12}$ Then, roughness and microleakage of the specimens were analyzed.

\section{Roughness Evaluation by Atomic Force Microscopy (AFM)}

For the analysis of roughness $\left(\mathrm{R}_{\mathrm{a}}\right), 30$ samples were used $(n=10)$ and divided into three groups $\left(G_{R}, G B_{R}, G_{R}\right)$. Roughness was analyzed in an atomic force microscope

Table 1: Treatment cycle of dental composite

\begin{tabular}{ll}
\hline Groups & Treatment cycle \\
\hline GA & Immersion in artificial saliva for 14 days (control group) \\
GB & Immersion in coffee for 14 days, for 15 minutes, 3x/day \\
GC & Immersion in CSD for 14 days, for 15 minutes, 3x/day \\
\hline
\end{tabular}

Table 2: Chemical composition of the beverages

\begin{tabular}{|c|c|c|c|c|}
\hline Solutions & Manufacturer & Composition & $p H$ & $\begin{array}{l}\text { Batch } \\
\text { number }\end{array}$ \\
\hline $\begin{array}{l}\text { Artificial } \\
\text { saliva }\end{array}$ & $\begin{array}{l}\text { Pharmacêutico }^{\circledR} \text {, } \\
\text { Maceió, AL, } \\
\text { Brazil }\end{array}$ & $\begin{array}{l}\text { CMC, potassium } \\
\text { chloride, dibasic } \\
\text { potassium } \\
\text { phosphate, } \\
\text { sodium chloride, } \\
\text { anhydrous } \\
\text { calcium chloride, } \\
\text { magnesium } \\
\text { chloride and } \\
\text { aspartame }\end{array}$ & 7.1 & $2357 / 11$ \\
\hline Coffee & $\begin{array}{l}\text { Pilão }^{\circledR} \text {, Jundiaí, } \\
\text { SP, Brazil }\end{array}$ & $\begin{array}{l}\text { Caffeine, amino } \\
\text { acids, lipids, } \\
\text { sugars and } \\
\text { B-complex } \\
\text { vitamins }\end{array}$ & 6.8 & 1346 \\
\hline $\begin{array}{l}\text { Cola soft } \\
\text { drink }\end{array}$ & $\begin{array}{l}\text { Coca-Cola }{ }^{\circledR}, \\
\text { Maceió, } \mathrm{AL}, \\
\text { Brazil }\end{array}$ & $\begin{array}{l}\text { Carbonated water, } \\
\text { sugar, vegetable } \\
\text { extracts, } \\
\text { flavorizers, } \\
\text { acidulant, caffeine, } \\
\text { phosphoric acid } \\
\text { and caramel food } \\
\text { coloring }\end{array}$ & 2.7 & 459879 \\
\hline
\end{tabular}


(SPM-9500J3 Shimadzu ${ }^{\circledR}$, Japan) equipped to an optical microscope (0.8-5× magnification) and a light source (Kyowa Optical, Kanagawa, Japan) with a Victor TMA14 seconds video monitor. The images were recorded and mapping procedure $50 \times 50 \mu \mathrm{m}$ imaging was used.

The $R_{a}$ value was determined to define the specimen's surface topography as the average deviation of a section profile calculated by equation:

(1) $R_{a}=\frac{1}{L} \int_{0}^{L}|f(x)| d x$.

$\mathrm{L}=$ length of the section; $\mathrm{f}(\mathrm{x})=$ displacement function.

\section{Microleakage Evaluation}

For the analysis of microleakage, 30 samples were used $(\mathrm{n}=10)$ and divided into three groups $\left(\mathrm{GA}_{\mathrm{M}}, \mathrm{GB}_{\mathrm{M}}, \mathrm{GC}_{\mathrm{M}}\right)$. The groups were submitted to aging tests thermal cycled for 1000 times $\left(5 \pm 2^{\circ} \mathrm{C}\right.$ and $\left.55 \pm 2^{\circ} \mathrm{C}\right)$ maintained for 15 seconds at each temperature. After these procedure, samples were submitted to the mechanical cycling. The samples were inserted to the mechanical cycling machine (Erios International, São Paulo, Brazil) and submitted to 100 thousand load cycles, frequency of 1 cycle/second to receive an intermittent vertical load of $50 \mathrm{~N}$ on the restoration. During the test, the samples were maintained in distilled water at $37^{\circ} \mathrm{C}$. The samples were stored in water at room temperature for 24 hours. After they were placed in $2 \%$ methylene blue for 48 hours. Then, the samples were rinsed and dried. Teeth were cut into three portions with a low speed saw (IsoMet ${ }^{\circledR} 1000$ Buehler) and assessed for dye penetration with a magnifying glass (Nikon Eclips E600, Tokyo, Japan) at 20× magnification (occlusal and cervical margins). A blind investigation was performed to score a mean of all interfaces. The score of dye penetration at the dental composite/tooth interface was made for enamel margins on a nonparametric scale as: $0=$ no microleakage; $1=$ dye penetration less than $1 / 2$ of axial wall; 2 = dye penetration more than $1 / 2$ of axial wall; 3 = dye penetration spreading along the axial wall.

\section{STATISTICAL ANALYSIS}

After recording the data, a comparison was made of the experimental and control groups. The one-way analysis of variance (ANOVA) was applied to assess the surface roughness and microleakage. The Tukey's test was set at 0.05 significance level.

\section{RESULTS}

Atomic force microscopy evaluation revealed that the results of surface roughness to $G_{R}$ presented the highest roughness, $62.69 \mathrm{~nm}$, while $\mathrm{GA}_{\mathrm{R}}, 42.30 \mathrm{~nm}$, exhibited lowest values the roughness after cycling. Graph 1 showed $\mathrm{R}_{\mathrm{a}}$ mean values of different experimental groups.
The t-test showed a statistically significant difference between $G_{R}$ and $G_{R}$, and $G_{R}$ and $G_{R}$, with $(p<0.05)$. No significant differences were found between groups $\mathrm{GB}_{\mathrm{R}}$ and $\mathrm{GC}_{\mathrm{R}}(\mathrm{p}>0.05)$.

Figures 1 and 2 present the images concerning $R_{a}$ values of experimental groups captured by AFM.

The frequency and differences of the microleakage obtained from different groups are showed in Table 3. The results of dye penetration for $\mathrm{GC}_{\mathrm{M}}$ presented the highest average microleakage of restorations.

No significant differences were found between groups $\mathrm{GA}_{\mathrm{M}}$ and $\mathrm{GB}_{\mathrm{M}}$ ( $\left.\mathrm{p}>0.05\right)$. The Mann-Whitney test, presented a statistically significant difference between $\mathrm{GA}_{\mathrm{M}}$ and $\mathrm{GC}_{\mathrm{M}}$, and $\mathrm{GB}_{\mathrm{M}}$ and $\mathrm{GC}_{\mathrm{M}}$, with $(\mathrm{p}<0.05)$.

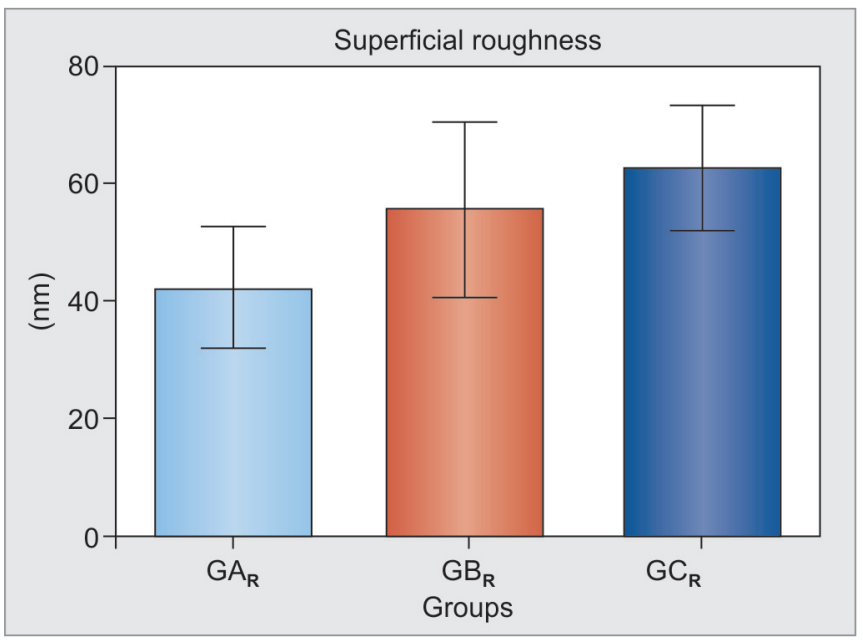

Graph 1: Surface roughness $\left(R_{a}\right)$ of the different experimental groups

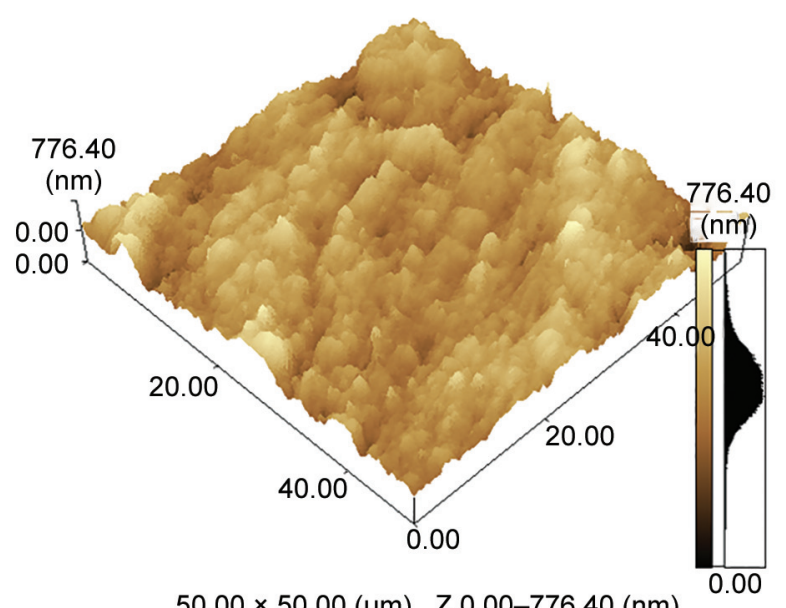

Fig. 1: Atomic force microscopy image of the tooth surface of $\mathrm{GB}_{\mathrm{R}}$ specimens

Table 3: Frequency of the microleakage scores obtained from the groups

\begin{tabular}{lllll}
\hline & \multicolumn{4}{c}{ Enamel margins (scores) } \\
\hline Groups & 0 & 1 & 2 & 3 \\
GA $_{M}$ & 10 & 6 & 4 & 0 \\
$\mathrm{~GB}_{\mathrm{M}}$ & 5 & 9 & 5 & 1 \\
$\mathrm{GC}_{\mathrm{M}}$ & 0 & 6 & 12 & 4 \\
\hline
\end{tabular}




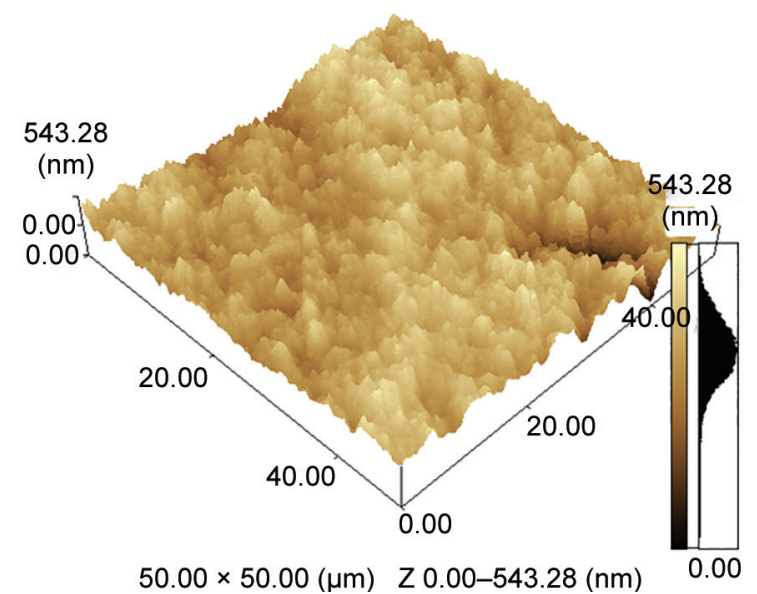

Fig. 2: Atomic force microscopy image of the tooth surface of $\mathrm{GC}_{\mathrm{R}}$ specimens

\section{DISCUSSION}

The potential for dental erosion with consumption of acidic beverages is an important consideration for nutritionists, dentists, and physicians counseling patients. Prolonged contact time between the beverage and enamel, dentin or composite surface increases the opportunity to occur erosion. ${ }^{13}$ In this study, to avoid interference of the resin's chemical composition on the beverages used, only one type of restorative material was used.

The testing period and period of immersion in the solution followed the protocol developed by von Fraunhofer and Rogers. ${ }^{12}$ These drinks are regularly consumed during the day and can take about 15 minutes to be ingested. Thus, the samples were immersed in drinks for 15 minutes and then in artificial saliva. The teeth were maintained in saliva between the beverages immersions to reproduce the conditions of normal oral environment. $^{14}$

The results of this study showed changes in the surface of the composite resin Z350 XT (3M/ESPE) being exposed for 14 days, accepting the hypothesis. $\mathrm{GB}_{\mathrm{R}}$ and $\mathrm{GC}_{\mathrm{R}}$ groups showed no significant differences, but had greater roughness compared with the group of $\mathrm{GA}_{\mathrm{R}}$ immersed in artificial saliva. According to Zero, ${ }^{15} \mathrm{pH}$ is the major factor to determine the erosive potential of a solution. When immersed in artificial saliva, resin Z350 XT (3M/ESPE) showed lower roughness values. This can be explained by the neutral $\mathrm{pH}$ of saliva. This result disagreement with Kitchens and Owens ${ }^{16}$ that found that the surface roughness not increase when the material was immersed in the coffee for the same period used in this study. However, the results of this study are in agreement with study of Dos Santos, et al, ${ }_{17}$ where found a significant degradation of the resin matrix in immersion in coffee at a high temperature. This higher temperature may have accelerated the degradation process, although in this study the different temperature were not considered. Atomic force microscopy analysis showed that there were areas where occurred a severe loss of matrix on the surface of the sample, as $\mathrm{GB}_{\mathrm{R}}$ where were found regions noticeably stained. This was probably caused because this beverage contains yellow dyes with high polarity which can penetrate in the organic matrix. ${ }^{18}$

The restorations subjected to $G_{R}$ had higher roughness than those immersed in artificial saliva, which is consistent with previous studies. ${ }^{19}$ This result can be explained by the presence of inorganic acids, such as phosphoric acid, which can promote the erosion of the resin surface. The penetration in the organic matrix of polymers causes disruption of the union between the filler particles and organic matrix. The composite Z350 XT (3M/ESPE) containing a combination of zirconia nanoparticles (diameter $10.5 \mathrm{~nm}$ ) and silica nanoparticles (nanoparticle diameter $75 \mathrm{~nm}$ ). Furthermore, these particles form nanoclusters $(0.6-1.4 \mu \mathrm{m})$ of zirconia and silica. These nanoclusters act as a single unit. The acids present in the CSD may spread through the matrix causing hydrolysis of the bond between the silane and the filler in the surface, removing these nanoclusters.

Marginal microleakage is an important factor for the success of restorative materials and it has been used in laboratory studies as an indicator of the maintenance of restorative materials. The clinical effects of the marginal microleakage are the penetration of bacteria and their subproducts in the interface tooth-restoration, contributing to the formation of secondary caries and postoperative sensibility. ${ }^{20}$

Thermal and mechanical load cycling increased significantly the microleakage for $\mathrm{GB}_{\mathrm{M}}$ and $\mathrm{GC}_{\mathrm{M}}$. Thermal cycling induces stress and degradation in interface due to the difference between tooth structures and restorative materials. ${ }^{21}$ Mechanical load cycling produces stress in the composite resin, and it is transmitted to the bonding interface. Interfaces less affected by microleakage before the aging test were more susceptible to thermal and load cycling. 22

The deterioration of physical property and changes in morphology of dental composites may be related with bond hydrolytic breakdown between matrix/silane and filler particles or fillers degradation. ${ }^{23,24}$ The long-term maintenance of the surface quality of materials is fundamental to improving the longevity of esthetic restorations. Another explanation for increased microleakage in specimens immersed in CSD may be degradation of adhesive bonding by phosphoric acid present in this drink. The results of presents study are consistent with the results reported by Navarro et al. ${ }^{25}$ 
Cola beverages and coffee have a low $\mathrm{pH}$ and can be sweetened with carbohydrates, which are metabolized by biofilm microorganisms, promoting organic acids which can contribute to the erosive potential of the hard dental tissues and restorative material. ${ }^{7,12}$ Therefore, further research into the intraoral environment is needed to confirm the results of this study.

\section{CONCLUSION}

Cola soft drink and coffee beverages change the surface roughness and increase the microleakage of restorations.

\section{CLINICAL SIGNIFICANCE}

Nowadays there is a high consumption of artificially sweetened soft drinks, sports drinks, high-energy beverages and coffee products by people that cause problems in composite resin restorations.

\section{ACKNOWLEDGMENTS}

The authors gratefully acknowledge the Institute of Chemistry and Biotechnology, Alagoas Federal University (UFAL) and University of Campinas (UNICAMP) for practical support.

\section{REFERENCES}

1. Colucci V, Dos Santos CD, Do Amaral FL, Corona AS, Catirse $\mathrm{AB}$. Influence of $\mathrm{NaHCO}_{3}$ powder on translucency of microfilled composite resin immersed in different mouthrinses. J Esthet Rest Dent 2009 Aug;21(4):242-248.

2. Yesilyurt C, Yoldas O, Altintas SH, Kusgoz A. Effects of foodsimulating liquids on the mechanical properties of a siloranebased dental composite. Dent Mater J 2009 May;28(3):362-367.

3. Pruthi G, Jain V, Kandpal HC, Mathur VP, Shah N. Effect of bleaching on color change and surface topography of composite restorations. Int J Dent 2010 Dec;22:1-7.

4. Nomoto R, McCabe JF. A simple acid erosion test for dental water-based cements. Dent Mater 2001 Jan;17(1):53-59.

5. Gusmão GM, De Queiroz TV, Pompeu GF, Menezes Filho PF, da Silva $\mathrm{CH}$. The influence of storage time and $\mathrm{pH}$ variation on water sorption by different composite resins. Ind J Dent Res 2013 Jan-Feb;24(1):60-65.

6. Kakaboura A, Fragouli M, Rahiotis C, Silikas N. Evaluation of surface characteristics of dental composites using profilometry, scanning electron, atomic force microscopy and gloss-meter. J Mater Sci Mater Med 2007 Jan;18(1):155-163.

7. Li H, Zou Y, Ding G. Dietary factors associated with dental erosion: a meta-analysis. PLoS One 2012 Aug;7(8):1-6.

8. Nicholson JW, Millar BJ, Czarnecka B, Limanowska-Shaw H. Storage of polyacid-modified resin composites ('compomers') in lactic acid solution. Dent Mater 1999 Nov;15(6):413-416.

9. Dennison JB, Sarrett DC. Prediction and diagnosis of clinical outcomes affecting restoration margins. J Oral Rehabil 2012 Apr;39(4):301-318.
10. Soldo M, Simeon P, Matijević J, Glavina D, Illeš D, Krmek SJ. Marginal leakage of class $\mathrm{V}$ cavities restored with siloranebased and methacrylate-based resin systems. Dent Mater J 2013;32(5):853-858.

11. Yap AU, Tan DT, Goh BC, Kuah, HG, Goh M. Effect of foodsimulating liquids on the flexural strength of composite and polyacid-modified composite restoratives. Oper Dent 2000 May-Jun;25(3):202-208.

12. von Fraunhofer JA, Rogers MW. Dissolution of dental enamel in soft drinks. Gen Dent 2004 Jul-Aug;52(4):308-312.

13. Seong J, Virani A, Parkinson C, Claydon N, Hellin N, Newcombe RG, et al. Clinical enamel surface changes following an intraoral acidic challenge. J Dent 2015 Apr 11. [Epub ahead of print]

14. Oncag G, Tuncer AV, Tosun YS. Acidic soft drinks effects on the shear bond strength of orthodontic brackets and a scanning electron microscopy evaluation of the enamel. Angle Orthod 2005 Mar;75(2):243-249.

15. Zero DT. Etiology of dental erosion-extrinsic factors. Eur J Oral Sci 1996 Apr;104(2):162-177.

16. Kitchens M, Owens BM. Effect of carbonated beverages, coffee, sports and high energy drinks, and bottled water on the in vitro erosion characteristics of dental enamel. J Clin Pediatr Dent 2007 Spring;31(3):153-159.

17. Dos Santos PA, Garcia PP, De Oliveira AL, Chinelatti MA, Palma-Dibb RG. Chemical and morphological features of dental composite resin: influence of light curing units and immersion media. Microsc Res Tech 2010 Mar;73(3): 176-181.

18. Fujita M, Kawakami S, Noda M, Sano I. Color change of newly developed esthetic restorative material immersed in foodsimulating solutions. Dent Mater J 2006 Jun;25(2):352-359.

19. Wongkhantee S, Patanapiradej V, Maneenut C, Tantbirojn D. Effect of acidic food and drinks on surface hardness of enamel, dentine, and tooth-coloured filling materials. J Dent 2006 Mar;34(3):214-220.

20. Taylor MJ, Lynch E. Microleakage. J Dent 1992 Feb;20(2):3-10.

21. Asaka Y, Amano S, Rikuta A, Kurokawa H, Miyazaki M, Platt JA, et al. Influence of thermal cycling on dentin bond strengths of single-step self-etch adhesive systems. Oper Dent 2007 Jan-Feb;32(1):73-78.

22. Aggarwal V, Logani A, Jain V, Shah N. Effect of cyclic loading on marginal adaptation and bond strength in direct vs indirect class II MO composite restorations. Oper Dent 2008 SepOct;33(5):587-592.

23. da Silva MA, Fardin AB, de Vasconcellos RC, Lde SM, Tonholo J, da Silva JG, et al. Analysis of roughness and surface hardness of a dental composite using atomic force microscopy and microhardness testing. Microsc Microanal 2011 Jun;17(3):446-451.

24. Hengtrakool C, Kukiattrakoon B, Kedjarune-Leggat U. Effect of naturally acidic agents on microhardness and surface micromorphology of restorative materials. Eur J Dent 2011 Jan;5(1):89-100.

25. Navarro R, Vicente A, Ortiz AJ, Bravo LA. The effects of two soft drinks on bond strength, bracket microleakage, and adhesive remnant on intact and sealed enamel. Eur J Orthod 2011 Feb;33(1):60-65. 